\title{
PENGARUH DISIPLIN KERJA DAN KEPUASAN KERJA TERHADAP KINERJA KARYAWAN PADA HOTEL BANYUALIT SPA'N RESORT LOVINA
}

\author{
Vidia Aulia ${ }^{1}$, Trianasari ${ }^{2}$ \\ ${ }^{12}$ Universitas Pendidikan Ganesha, Singaraja \\ e-mail: vidiaaulia332@gmail.com, nanatrianasari01@gmail.com
}

\begin{abstract}
Abstrak
Penelitian ini bertujuan untuk menguji pengaruh (1) disiplin kerja dan kepuasan kerja secara bersamasama terhadap kinerja karyawan; (2) disiplin kerja terhadap kinerja karyawan; (3) kepuasan kerja terhadap kinerja karyawan. Desain penelitian yang digunakan adalah kuantitatif kausal. Subjek dalam penelitian ini adalah seluruh karyawan Hotel Banyualit Spa'n Resort Lovina. Populasi dalam penelitian ini berjumlah 35. Metode pengumpulan data yang digunakan adalah survey dengan menggunakan kuesioner sebagai instrumen penelitian. Data dianalisis dengan regresi linear berganda dengan memenuhi asumsi-asumsi klasik. Hasil analisis menunjukkan bahwa secara simultan disiplin kerja dan kepuasan kerja berpengaruh signifikan terhadap kinerja karyawan. Selanjutnya, disiplin kerja dan kepuasan kerja berpengaruh secara parsial dan signifikan terhadap kinerja karyawan.
\end{abstract}

Kata Kunci: disiplin kerja, kepuasan kerja, kinerja karyawan, regresi linear berganda

\begin{abstract}
This research aims to examine the effects (1) work discipline and job satisfaction simultaneously on employee performance; (2) work discipline on employee performance; (3) job satisfaction on employee performance. Design research used was quantitative causal. The subject in this study were all employees of Hotel Banyualit Spa $n$ Resort Lovina. The population in this study was 35 employees. The method of data collection used was survey using questionnaire as the research instrument. The results of multiple linear regression analyses show that work discipline and job satisfaction have simultaneous and significant effect on employee performance. Furthermore, both work discipline and job satisfaction partially and significantly influence employee performance.
\end{abstract}

Keywords: work discipline, job satisfaction, employee performance, multiple linear regression 
JMPP, Vol. 4, No. 1, March 2021

p-ISSN: 2654-9719

\section{PENDAHULUAN}

Perubahan lingkungan bisnis yang sangat cepat, menuntut peran sumber daya manusia dalam keunggulan bersaing. Hal ini juga berarti bahwa organisasi harus dapat meningkatkan hasil kerja yang diraih sekarang untuk dapat memperoleh hasil kerja yang lebih baik di masa depan. Salah satu sumber daya organisasi yang memiliki peran penting dalam mencapai tujuannya adalah sumber daya manusia. Oleh karena pentingnya peran manusia dalam kompetisi baik jangka pendek maupun jangka panjang dalam operasional bisnis, suatu organisasi harus memiliki nilai lebih dibandingkan dengan organisasi lainnya. Manajer yang berhasil adalah mereka yang mampu melihat sumber daya manusia sebagai aset yang harus dikelola sesuai dengan kebutuhan bisnisnya. Berkaitan dengan sumber daya manusia agar dapat menjadi sumber keunggulan bersaing (competitive advantage) adalah melalui peningkatan modal manusia (human capital) untuk dapat mengenal dan beradaptasi dengan lingkungan yang selalu berubah (Bangun, 2012).

Selain sumber daya manusia, yang merupakan hal penting bagi perusahaan adalah kinerja yang merupakan suatu hal yang kompleks harus diperhatikan secara ketat oleh setiap perusahaan (Sajangbati, 2013). Dalam meningkatkan modal manusia agar dapat terus beradaptasi dengan lingkungan bisnis yang terus berubah, maka perlu adanya peningkatan kinerja yang diinginkan pihak pemberi kerja maupun para pekerja. Pemberi kerja menginginkan kinerja karyawannya baik untuk kepentingan peningkatan hasil kerja dan keuntungan perusahaan (Bangun, 2012). Kinerja (performance) merupakan hasil pekerjaan yang dicapai seseorang berdasarkan persyaratan-persyaratan pekerjaan (job requirement). Dengan kata lain kinerja merupakan serangkaian kegiatan sebagai suatu proses yang dilakukan oleh karyawan dalam usahanya mencapai hasil sesuai yang telah ditetapkan (Prasetyo \& Marlina, 2019). Selanjutnya kinerja juga merupakan hasil kerja seorang karyawan selama periode tertentu dibandingkan dengan berbagai kemungkinan seperti standar, target/sasaran atau kriteria yang telah ditentukan terlebih dahulu dan disepakati bersama dalam perusahaan (Arda, 2017; Fitrianto, 2016).

Salah satu faktor yang dapat memengaruhi kinerja yaitu disiplin kerja. Agar kinerja karyawan semakin meningkat perlu terciptanya disiplin kerja dan kepuasan kerja (Zahara \& Hidayat, 2017). Disiplin sangat penting untuk perkembangan perusahaan karena dapat dijadikan sebagai alat untuk memotivasi agar dapat mendisiplinkan diri dalam melaksanakan pekerjaan baik secara perorangan maupun kelompok (Asmawiyah, 2018). Disiplin merupakan suatu tingkah laku dan perbuatan yang saling menghormati dan menghargai serta patuh terhadap peraturanperaturan yang dibuat oleh perusahaan baik tertulis maupun tidak tertulis, serta sanggup untuk menjalankan dan menerima sanksi apabila karyawan melanggar peraturan dalam perusahaan atau instansi (Syafrina, 2017). Lebih jauh jika perusahaan mampu meningkatkan disiplin kerja pada karyawannya maka akan memperoleh keuntungan yang lebih besar, dengan meningkatkan disiplin kerja maka pekerjaan akan lebih cepat diselesaikan, kerusakan akan dapat dikurangi, absensi akan dapat diperkecil dan kemungkinan perputaran juga dapat diperkecil (Syafrina, 2017).

Selain disiplin kerja, kepuasan kerja juga merupakan faktor yang dapat memengaruhi kinerja karyawan. Sikap puas atau tidak puas karyawan dapat diukur dari sejauh mana perusahaan atau organisasi dapat memenuhi kebutuhan dan keinginan karyawan dalam rangka melakukan tugas dan tanggung jawab. Kepuasan kerja akan membentuk kinerja karyawan dalam bekerja, sehingga dengan membentuk budaya kerja yang baik dengan memberikan rasa nyaman dalam lingkungan dan memiliki kualitas kehidupan kerja yang baik untuk dapat melaksanakan tugasnya dengan tepat sesuai dengan tujuan yang telah ditetapkan oleh organisasi (Susanto, 2019). Kepuasan kerja adalah keadaan emosional karyawan yang menyenangkan atau tidak menyenangkan terhadap tugas atau pekerjaan yang telah dibebani (Handoko, 2001) yang berhubungan dengan situasi kerja, kerjasama antar karyawan (Sutrisno, 2013). Setiap individu memilki tingkat kepuasan yang berbeda sesuai dengan sistem nilai yang berlaku pada dirinya. 
Selain itu, perusahaan dapat memberikan rasa puas pada karyawan agar tercipta perasaan senang pada karyawan saat melakukan pekerjaannya.

Hotel Banyualit Spa'n Resort merupakan salah satu hotel yang yang didirikan pada tahun 1981 dan berlokasi di kawasan pantai Kalibukbuk Lovina, Bali Utara. Pada Hotel Banyualit Spa'n Resort karyawan dituntut untuk melakukan pelayanan sebaik mungkin, namun beberapa karyawan masih memiliki kinerja yang tergolong lemah. Berdasarkan hasil observasi, karyawan masih belum dapat menyelesaikan tugasnya sesuai waktu yang ditetapkan, misalnya seperti bagian housekeeping masih belum bisa membersihkan kamar sesuai standar waktu yang ditetapkan. Kemudian kualitas pekerjaan, beberapa karyawan masih banyak menerima keluhan seperti AC yang mati, banyak nyamuk dari tamu karena karyawan kurang teliti saat bekerja. Selain itu, kehadiran pada saat jam kerja misalnya security masih tidak berada di tempatnya saat jam kerja. Fenomena ini dapat menyebabkan menurunnya produktifitas pada hotel (Almigo, 2004).

Karyawan Hotel Banyualit Spa'n Resort merupakan salah satu aset yang memegang peranan penting dalam perkembangan Hotel Banyualit Spa'n Resort, karena dengan karyawan tersebut, kegiatan perusahaan dapat terlaksana dengan baik. Oleh karena itu, karyawan dituntut untuk disiplin dalam bekerja. Hotel Banyualit Spa'n Resort membuat kebijakan - kebijakan yang harus dipatuhi para karyawannya di antaranya karyawan diwajibkan untuk mengikuti kegiatan doa bersama di pagi hari, karyawan dilarang datang terlambat atau tanpa keterangan (alpha) dan karyawan yang melakukan kesalahan dalam kerja harus bertanggung jawab atas tindakannya. Apabila karyawan tidak mematuhi kebijakan tersebut maka konsekuensinya adalah karyawan diberikan sanksi dan teguran pada karyawan. Hotel Banyualit Spa'n Resort sudah menggunakan sistem absensi sidik jari, maka apabila karyawan yang datang terlambat atau tanpa keterangan akan langsung dipotong gaji. Berdasarkan observasi awal ditemukan bahwa beberapa karyawan masih cenderung datang terlambat. Pada umumnya alasan keterlambatan tersebut disebabkan oleh terlambat bangun, rasa malas dan kurangnya teguran dari atasan sehingga karyawan masih banyak melanggar peraturan. Penurunan disiplin kerja akan berdampak pada kinerjanya. Setiap prusahaan harus mampu meningkatkan disiplin kerja pada karyawan agar tujuan perusahaan dapat tercapai dengan keuntungan yang lebih besar. Hal ini dipertegas oleh Meilany \& Ibrahim (2015) yang mengatakan bahwa peningkatan disiplin menjadi bagian yang penting dalam manajemen sumber daya manusia sebagai faktor penting dalam meningkatkan kinerja. Dengan kata lain, semakin tinggi disiplin maka semakin meningkatnya kinerjanya, semakin baik pula seseorang dalam memanfaatkan waktu sehingga kedepannya karyawan dapat menyelesaikan tugas serta tanggung jawab dapat terselesaikan.

Selain disiplin kerja, rendahnya kinerja karyawan dipengaruhi oleh kepuasan kerja karyawan yang rendah (Subakti, 2013). Dengan kata lain rendahnya kepuasan kerja karyawan mengakibatkan karyawan kurang merasa puas akan pekerjaannya. Berdasarkan hasil observasi awal, beberapa karyawan Hotel Banyualit Spa'n Resort menyatakan kurang puas terhadap pekerjaannya, misalnya terkait pembayaran di mana karyawan merasa pembayaran yang diberikan hotel tidak sebanding dengan pekerjaan yang dilakukan. Selain itu, hotel juga perlu memberikan promosi jabatan bagi karyawan yang kinerjanya baik, sehingga karyawan akan merasa puas dalam bekerja. Karyawan yang memiliki tingkat kepuasan yang tinggi akan meningkatkan kinerjanya. Hal ini dipertegas oleh Damayanti (2018) yang menyatakan kepuasan kerja akan tercapai apabila kebutuhan karyawan terpenuhi melalui pekerjaan, dimana kepuasan kerja merupakan keadaan emosi yang berasal dari penilaian pekerjaan seseorang.

Dalam literatur disebutkan bahwa rendahnya kinerja karyawan dipengaruhi oleh disiplin kerja dan kepuasan kerja (Meiliana et al., 2019; Prasetyo \& Marlina, 2019). Namun, penelitian Sumbung (2016) menyimpulkan bahwa disiplin tidak berpengaruh signifikan terhadap kinerja. Selain itu, Windari et al. (2014) juga menyimpulkan bahwa pada variabel kepuasan kerja tidak berpengaruh signifikan terhadap kinerja. 
Berdasarkan uraian di atas ada kesenjangan dalam literatur mengenai hubungan disiplin kerja, kepuasan kerja dan kinerja. Sementara itu, dalam operasional bisnis praktis ditemukan pula fenomena terkait ketiga variabel tersebut di mana disiplin kerja, kepuasan kerja dan kinerja belum optimal. Hal tersebut dapat memengaruhi keberlangsungan kegiatan operasional hotel apabila tidak diantisipasi dengan baik.

Berdasarkan latar belakang yang diuraikan di atas, dapat dirumuskan masalah penelitian sebagai berikut. (1) Apakah ada pengaruh disiplin kerja dan kepuasan kerja terhadap kinerja karyawan? (2) Apakah ada pengaruh disiplin kerja terhadap kinerja karyawan? (3) Apakah ada pengaruh kepuasan kerja terhadap kinerja karyawan?

Berdasarkan rumusan masalah di atas, maka tujuan penelitian ini adalah untuk memperoleh temuan eksplanatif yang teruji tentang pengaruh sebagai berikut. (1) Pengaruh disiplin kerja dan kepuasan kerja terhadap kinerja karyawan. (2) Pengaruh disiplin kerja terhadap kinerja karyawan.

(3) Pengaruh kepuasan kerja terhadap kinerja karyawan.

\section{KAJIAN PUSTAKA Kinerja Karyawan}

Kinerja adalah suatu hasil kerja yang dicapai oleh seseorang dalam melaksanakan tugastugas yang dibebankan kepadanya yang didasarkan atas kecakapan, pengalaman, dan kesungguhan serta waktu. Besarnya hasil yang telah dicapai atau yang diberikan seorang karyawan terhadap kemajuan serta perkembangan perusahaannya disebut juga kinerja (Paruru et al., 2016). Kinerja juga merupakan suatu hasil atau efek samping atas usaha yang telah dilakukan berdasarkan prestasi yang dihasilkan baik prestasi yang diraih secara individu maupun secara berkelompok (Subagio, 2015). Arda (2017) juga mengemukakan kinerja adalah hasil kerja seorang karyawan selama periode tertentu dibandingkan dengan berbagai kemungkinan seperti standar, target/sasaran atau kriteria yang telah ditentukan terlebih dahulu dan disepakati bersama. Zahara \& Hidayat (2017) mengemukakan: kinerja merupakan hasil kerja karyawan yang dapat diamati dan dapat diukur. Ukuran kinerja dapat dilihat dari jumlah dan mutu pekerjaan yang telah sesuai dengan standar yang ditetapkan perusahaan

Pengukuran kinerja di setiap masing-masing perusahaan menggunakan indikator yang berbeda-beda, tergantung pada pendekatan yang digunakan setiap perusahaan. Menurut Bangun (2012) indikator kinerja meliputi: (1) Jumlah pekerjaan, adalah jumlah pekerjaan yang diselesaikan seseorang/karyawan berdasarkan waktu dan standar yang telah ditetapkan. Jumlah pekerjaan diukur melalui jumlah pekerjaan yang dapat diselesaikan sesuai dengan standar perusahaan. (2) Kualitas pekerjaan, kualitas kerja diukur melalui kualitas pekerjaan yang dihasilkan serta kesempurnaan tugas terhadap keterampilan dan kemampuan yang dimiliki karyawan. Hasil pekerjaan yang dilakukan mendekati sempurna atau memenuhi tujuan yang diharapkan dari pekerjaan tersebut. (3) Ketepatan waktu, ketepatan waktu diukur melalui tingkat aktivitas/hasil kerja yang dapat diselesaikan berdasarkan waktu yang ditetapkan. (4) Kehadiran, kehadiran diukur melalui karyawan yang mampu meminimalisir ketidakhadiran saat bekerja. (5) Kemampuan kerja sama, kemampuan kerja sama diukur melalui kemampuan karyawan bekerjasama antar rekan sekerja lainnya.

\section{Disiplin Kerja}

Disiplin kerja yang baik dapat dilihat dari tingginya kesadaran pada karyawan dalam mematuhi serta menaati segala peraturan yang berlaku dan besarnya rasa tangguang jawab akan tugas dari masing-masing karyawan (Syafrina, 2017). Kedisiplinan lebih dapat diartikan suatu sikap atau perilaku dan perbuatan yang sesuai dengan peraturan-peraturan yang telah ditetapkan oleh perusahaan atau instansi yang bersangkutan baik secara tertulis maupun tidak tertulis (Paruru et al., 2016). Disiplin kerja adalah alat yang digunakan manajer untuk berkomunikasi dengan karyawan agar bersedia untuk mengubah perilaku serta sebagai upaya 
untuk meningkatkan kesadaran dan kesediaan karyawan dalam mentaati peraturan perusahaan (Rivai, 2003). Disiplin kerja merupakan sikap atau bentuk kepatuhan karyawan terhadap peraturan yang berlaku diperusahaan berdasarkan kesadaran diri dan kesediaan karyawan akan tugas dan pekerjaan yang dibebankan (Ernawati, 2016; Zahara \& Hidayat, 2017).

Dalam pengukuran disiplin pada setiap karywan di masing-masing perusahaan memliki kriteria yang berbeda-beda. Menurut (Sudjadi, 2005) indikator disiplin yaitu: (1) Ketepatan waktu, ketepatan waktu dalam melaksanakan tugas, ketepatan waktu saat masuk kerja dan pulang kerja serta ketepatan waktu dalam melaksanakan tugas. (2) Kepatuhan pada peraturan, kepatuhan pada aturan prosedur kerda dan kepatuhan dalam melaksanakan tugas yang diberikan. (3) Ketaatan pada hasil kerja yang mengacu pada pendapat, ketaatan pada hasil kerja berdasarkan tanggung jawab dalam menyelesaikan pekerjaan secara individu maupun kelompok.

\section{Kepuasan Kerja}

Kepuasan kerja adalah sikap emosional yang menyenangkan serta mencintai pekerjaannya (Giyarto, 2018). Menurut Sutrisno (2013) kepuasan kerja juga merupakan suatu sikap karyawan terhadap pekerjaan yang berhubungan dengan situasi kerja, kerjasama antar karyawan, imbalan yang diterima, dan hal-hal yang menyangkut faktor fisik dan psikologis. Kepuasan kerja akan membentuk kinerja karyawan dalam bekerja, sehingga dengan membentuk budaya kerja yang baik dengan memberikan rasa nyaman dalam lingkungan dan memiliki kualitas kehidupan kerja yang baik untuk dapat melaksanakan tugasnya dengan tepat sesuai dengan tujuan yang telah ditetapkan oleh organisasi (Susanto, 2019). Kepuasan kerja merupakan generalisasi sikap-sikap terhadap pekerjaannya berdasarkan atas aspek-aspek pekerjaannya yang bermacam-macam. Hasibuan (2001) juga berpendapat bahwa kepuasan kerja adalah sikap emosional yang menyenangkan dan mencintai pekerjaannya. Sikap ini dicerminkan oleh moral kerja, kedisiplinan dan prestasi kerja. Kepuasan kerja dinikmati dalam pekerjaan, luar pekerjaan dan kombinasi dalam dan luar pekrjaan.

Menurut (Winardi, 2004) indikator kepuasan kerja yaitu: (1) Pekerjaan Itu sendiri, pekerjaan yang menarik, menantang, pekerjaan yang tidak membosankan serta pekerjaan yang dapat memberikan status. (2) Pembayaran (upah-gaji), pembayaran/gaji yang diberikan sesuai dengan beban pekerjaan yang diberikan. (3) Supervise, kemampuan atasan memberikan bantuan teknis serta dukungan prilaku kepada bawahannya. (4) Kesempatan untuk promosi, kesempatan yang diberikan atasan untuk memproleh peningkatan karir selamam bekerja. (5) Ciriciri/sifat para rekan sekerja, rekan kerja yang dapat mendukung secara social yang berhubungan dengan antar karyawan maupun atasan.

\section{Pengaruh Disiplin Kerja Dan Kepuasan Kerja Terhadap Kinerja}

Disiplin kerja dan kepuasan kerja karyawan sangat memengaruhi kinerja karyawan suatu perusahaan. Semakin tinggi tingkat kedisiplinan karyawan dan tingkat kepuasan karyawan akan meningkatkan kinerjanya (Prasetyo \& Marlina, 2019). Dalam penelitian menemukan bahwa disiplin kerja dan kepuasan kerja berpengaruh positif terhadap kinerja karyawan (Meiliana et al., 2019; Prasetyo \& Marlina, 2019). Begitu pula penelitian yang dilakukan Meiliana et al. (2019) menunjukkan bahwa disiplin kerja dan kepuasan kerja secara simultan (bersama-sama) mempunyai pengaruh terhadap kinerja karyawan laboratorium.

\section{Pengaruh Disiplin Kerja Terhadap Kinerja}

Karyawan yang tingkat disiplinnya baik, maka kinerja akan baik, sedangkan karyawan yang tingkat disiplinnya rendah, tingkat kinerjanya akan rendah pula (Ernawati, 2016). Menurut Hasibuan (dalam Syafrina, 2017) kedisiplinan bagi manajemen sumber daya manusia adalah fungsi operatif terpenting karena semakin baik disiplin karyawan, maka semakin tinggi prestasi yang dicapai karyawan. Tanpa dsiplin yang baik prusahaan tidak akan mencapai hasil yang 
optimal. Hal ini dipertegas oleh Untari (2018) yang menyimpulkan bahwa pengaruh antara disiplin kerja dengan kinerja pegawai sangat erat sekali, jika kedisiplinan seseorang karyawan baik, maka akan berakibat kinerjanya akan semakin baik pula.

Disiplin kerja yang baik mencerminkan besarnya rasa tanggung jawab seseorang terhadap tugas-tugas yang diberikan kepadanya dengan segala peraturan yang disusun oleh perusahaan. Karyawan yang berperilaku disiplin biasanya akan berhasil dalam pekerjaan karena mereka mampu mengatur apa yang menjadi prioritasnya sehingga kinerjanya juga akan baik (Rivai, 2009). Hal tersebut juga didukung oleh penelitian yang dilakukan oleh Zahara \& Hidayat (2017) bahwa terdapat pengaruh yang signifikan antara disiplin kerja terhadap kinerja karyawan. Hasil penelitian Paruru et al. (2016) menunjukkan bahwa disiplin kerja berpengaruh positif dan signifikan terhadap variabel kinerja karyawan. Ini berarti semakin baik disiplin kerja dari karyawan, maka akan semakin baik pula kinerja dari karyawan tersebut.

\section{Pengaruh Kepuasan Kerja Terhadap Kinerja Karyawan}

Menurut Wibowo dalam Sari (2015) kepuasan kerja merupakan prediktor kinerja, karena kepuasan kerja mempunyai korelasi moderat dengan kinerja. Kepuasan kerja akan membentuk kinerja karyawan dalam bekerja, sehingga dengan membentuk budaya kerja yang baik dengan memberikan rasa nyaman dalam lingkungan dan memiliki kualitas kehidupan kerja yang baik untuk dapat melaksanakan tugasnya dengan tepat sesuai dengan tujuan yang telah ditetapkan oleh organisasi Susanto (2019). Dengan demikian dapat disimpulkan bahwa tinggi rendahnya kepuasan kerja karyawan akan berpengaruh terhadap kinerja. Hal ini didukung oleh hasil penelitian Prasetyo \& Marlina (2019) yang menyatakan bahwa kepuasan kerja memiliki pengaruh yang positif dan signifikan terhadap kinerja karyawan. Hal ini memiliki implikasi bahwa dengan semakin meningkatnya kepuasan kerja maka akan berdampak pada semakin tingginya kinerja. Hasil penelitian Manik \& Syafrina (2018) juga mengatakan bahwa kepuasan kerja berpengaruh signifikan terhadap kinerja. Jadi untuk meningkatkan kinerja karyawan dapat dilakukan dengan cara memberikan kepuasan kerja terhadap karyawan.

\section{METODOLOGI \\ Desain Penelitian}

Penelitian ini dilakukan untuk mengetahui pengaruh disiplin kerja dan kepuasan kerja terhadap kinerja karyawan pada Hotel Banyualit Spa'n Resort Lovina. Dalam penelitian ini terdapat dua variabel bebas yaitu disiplin kerja $\left(X_{1}\right)$ dan Kepuasan kerja $\left(X_{2}\right)$ serta variabel terikat yaitu kinerja $(\mathrm{Y})$.

Adapun desain penelitian yang digunakan dalam penelitian ini adalah desain kuantitatif kausal. Desain penelitian kuantitatif kausal yaitu untuk mengkaji hubungan sebab-akibat antara faktor tertentu yang menjadi penyebab gejala yang diselidiki. Desain penelitian kausal memiliki beberapa tahapan yaitu (1) merumuskan masalah, (2) mengkaji teori, (3) merumuskan hipotesis, (4) mengumpulkan data, (5) mengolah data, (6) membuat kesimpulan dan saran.

Dalam penelitian yang menjadi subjek dari ini adalah karyawan Hotel Banyualit Spa'n Resort Lovina dan objek dalam penelitian ini adalah disiplin kerja, kepuasan kerja dan kinerja karyawan. Penelitian ini merupakan penelitian populasi yang berarti seluruh karyawan pada Hotel Banyualit Spa'n Resort Lovina dengan jumlah 35 karyawan.

\section{Metode dan Teknik Analisis Data}

Analisis data yang digunakan pada penelitian ini adalah analisis regresi linear berganda dengan tujuan untuk mengetahui pengaruh antar variabel bebas (disiplin kerja dan kepuasan kerja). Pada penelitian ini pengolahan data yang digunakan yaitu program SPSS. Data yang diinput dalam program SPPS yaitu kinerja $(Y)$ sebagai variabel terikat, disiplin kerja $\left(\mathrm{X}_{1}\right)$ dan 
kepuasan kerja $\left(\mathrm{X}_{2}\right)$ sebagi variabel bebas. Data yang digunakan dalam penelitian ini harus memenuhi syarat uji asumsi klasik sebelum dianalisis dengan regresi linear berganda. Berdasarkan variabel $\mathrm{X}_{1}, \mathrm{X}_{2}$, maka didapatkan persamaan regresi sebagai berikut (Ghozali, 2005)

$$
\begin{array}{ll}
Y=\alpha+\beta_{1} \mathrm{X}_{1}+\beta_{2} \mathrm{X}_{2}+\varepsilon & \text { (1) } \\
\text { Keterangan: } \\
\mathrm{Y}=\text { Variabel terikat (Kepuasan kerja karyawan) } \\
\alpha & =\text { Konstanta } \\
\beta_{1} & =\text { Koefisien regresi dari } \mathrm{X}_{1} \\
\beta_{2} & =\text { Koefisien regresi dari } \mathrm{X}_{2} \\
\mathrm{X}_{1} & =\text { Variabel Kompensasi } \\
\mathrm{X}_{2} & =\text { Variabel Lingkunga Kerja } \\
\varepsilon & =\text { eror }
\end{array}
$$

Analisis regresi linear berganda digunakan untuk mengetahui pengaruh disiplin kerja dan kepuasan kerja terhadap kinerja karyawan pada Hotel Banyualit Spa'n Resort. Untuk memproleh hasil yang lebih akurat pada analisis regresi linear berganda maka dilakukan asumsi klasik yang harus dipenuhi terlebih dahulu sebelum menggunakan analisis regresi linear berganda sebagai alat untuk menganalisis pengaruh variabel-variabel yang diteliti.

\section{HASIL DAN PEMBAHASAN Uji Validitas dan Reliabilitas}

Suatu kuiseoner dikatakan valid (sah) jika pertanyaan/pernyataan pada kuiseoner mampu untuk mengungkapkan suatu yang akan diukur. Instrumen penelitian dikatakan valid apabila korelasi tiap faktor tersebut positif dan bernilai lebih besar dari tabel yang terkait. Pengolahan data untuk mengukur validitas butir kuiseoner tersebut dibantu dengan program Statistical Package for Social Sience (SPSS) 24.0 for Windows.

Suatu kuiseoner dikatakan reliabel (andal) jika jawaban responden terhadap pertanyaan/pernyataan yang ada konsisten atau stabil dari waktu ke waktu. Kriteria suatu instrumen penelitian dapat dikatakan reliabel apabila reliabilitas $\left(r_{i}\right)>0,06$. Pengolahan data dalam penelitian ini dibantu dengan program Statistical Package for Social Sience (SPSS) 24.0 for Windows.

\section{Hasil Analisis dan Pembahasan Gambaran Tempat Penelitian Data Karakteristik Responden}

Tabel 4.2

Data Karakteristik Responden

\begin{tabular}{|l|l|c|c|}
\hline \multicolumn{1}{|c|}{ Deskriptif } & \multicolumn{1}{|c|}{ Keterangan } & Frekuensi & Persentase (\%) \\
\hline Jenis Kelamin & Laki-Laki & 16 & 46 \\
& Perempuan & 19 & 54 \\
\hline & Jumlah & 35 & 100 \\
\hline \multirow{3}{*}{ Umur } & 21-30 tahun & 25 & 71 \\
& $31-40$ tahun & 8 & 23 \\
& $41-50$ tahun & 2 & 6 \\
\hline & Jumlah & 35 & 100 \\
\hline
\end{tabular}

Sumber: Data Diolah, 2020

Berdasarkan data pada tabel 4.2, dapat dilihat bahwa responden yang terdapat pada penelitian ini adalah responden laki-laki sebanyak 16 orang atau sebesar $46 \%$ dan responden perempuan sebanyak 19 orang atau sebesar 54\%. Hal ini menunjukkan bahwa sebagian besar responden adalah perempuan. Dilihat dari segi usia, responden yang berusia 21-30 tahun sebanyak 25 orang atau sebesar $71 \%$, yang berusia 31-40 tahun sebanyak 8 orang atau sebesar 
$23 \%$ dan berusia 41-50 tahun sebanyak 2 orang atau sebesar $6 \%$. Hal ini menunjukkan bahwa sebagian besar responden berumur 21-30 tahun.

\section{Uji Asumsi Klasik}

Sebelum dilakukan analisis regresi linear berganda, dilakukan uji asumsi klasik yaitu uni normalitas, uji multikolinearitas, dan uji heteroskedastisitas. Uji normalitas bertujuan untuk menguji apakah dalam model regresi, variabel pengganggu atau residual memiliki distribusi normal. Uji Kolmogorov-Smirnov untuk mengetahui data yang diguna kan berdistribusi normal atau tidak, kriteria pengujian normalitas menggunakan probabilitas yang diperoleh dengan level signifikan sebesar 0,05.

\section{Uji Normalitas}

Tabel 4.4 Hasil Uji Normalitas

One-Sample Kolmogorov-Smirnov Test

\begin{tabular}{|c|c|c|}
\hline & & $\begin{array}{c}\text { Unstandardized } \\
\text { Residual }\end{array}$ \\
\hline$N$ & & 35 \\
\hline Normal Parameters ${ }^{a}$ & Mean & 0,0000000 \\
\hline & Std. Deviation & 1,41665272 \\
\hline Most Extreme Differences & Absolute & 0,119 \\
\hline & Positive & 0,116 \\
\hline & Negative & $-0,119$ \\
\hline Kolmogorov-Smirnov $Z$ & & 0,702 \\
\hline Asymp. Sig. (2-tailed) & & 0,708 \\
\hline
\end{tabular}

a. Test distribution is Normal.

Sumber: Data Diolah, 2020

Berdasarkan data pada tabel 4.4 dapat dilihat bahwa nilai Kolmogorov Smirnov sebesar 0,702 dengan nilai signifikansi sebesar 0,708 di mana nilai ini lebih dari 0,05 yang berarti nilai residual berdistribusi secara normal. Apabilia dilihat dari sebaran titik-titik pada garis diagonal maka akan terlihat seperti pada gambar 4.1. 


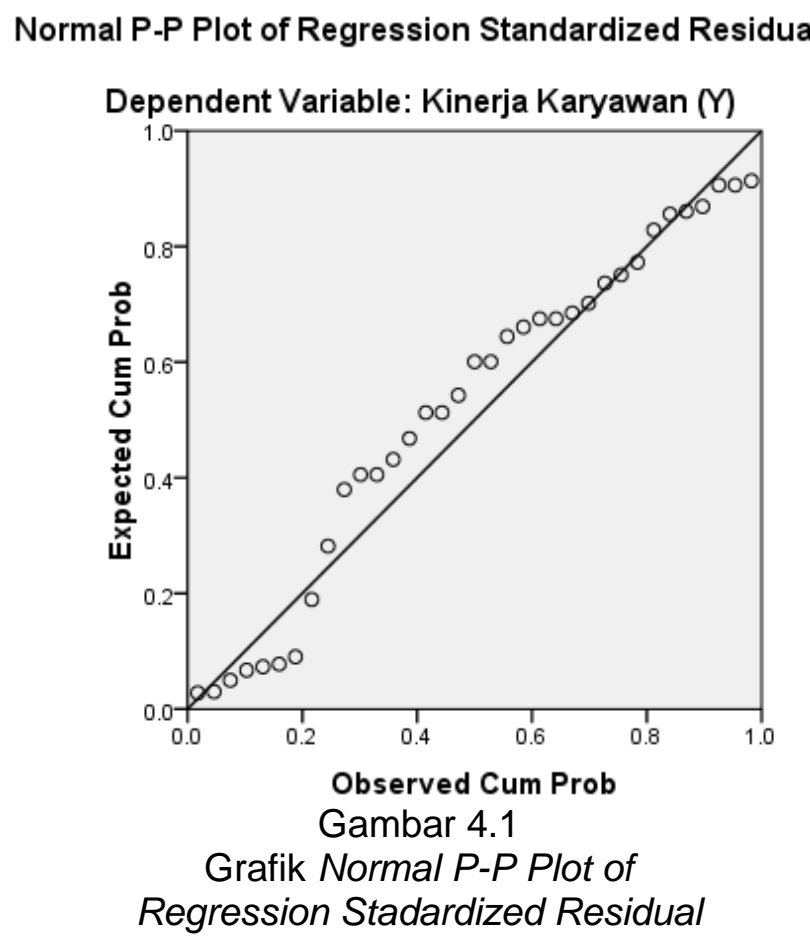

Dari hasil analisis grafik tersebut maka dapat dipastikan bahwa data berdistribusi normal karena data menyebar disekitar garis diagonal dan mengikuti arah garis diagonal, maka model regresi memenuhi asumsi normalitas.

\section{Uji Multikolinearitas}

Uji ini bertujuan untuk mengetahui ada tidaknya hubungan antara variabel bebas yang satu dengan variabel yang lainnya. Untuk mendekati adanya multikolinearitas dapat dilihat dari nilai Variance Inflation Factor (VIF) dan nilai Tolerance. Tolerance mengukur variabilitas variabel bebas yang terpilih yang tidak dapat dijelaskan oleh variabel lainnya. Jadi, nilai tolerance rendah sama dengan nilai VIF tinggi (karena $\mathrm{VIF}=1 /$ tolerance) dan menunjukkan adanya kolinearitas yang tinggi. Berdasarkan aturan Variance Inflation Factor (VIF) dan tolerance, maka apabila VIF melebihi angka 10 atau tolerance kurang dari 0,10 maka dinyatakan terjadi gejala multikolinearitas. Sebaiknya apabila nilai VIF kurang dari 10 atau tolerance lebih dari 0,10 maka dinyatakan tidak terjadi gejala multikolinearitas. Ringkasan hasil uji multikolinearitas disajikan pada tabel 4.5 berikut.

Tabel 4.5

Ringkasan Hasil Uji Multikolinearitas

\begin{tabular}{|l|c|c|c|}
\hline \multirow{2}{*}{ Model } & \multicolumn{2}{|c|}{ Collinearity Statistics } & \multirow{2}{*}{ Keterangan } \\
\cline { 2 - 3 } & Tolerance & VIF & \multirow{2}{*}{ Bebas Multikolinearitas } \\
\hline Disiplin Kerja & 0,131 & 7,618 & Bebas Multikolinearitas \\
\hline Kepuasan Kerja & 0,131 & 7,618 & B \\
\hline
\end{tabular}

Sumber: Data Diolah, 2020

Berdasarkan data pada tabel 4.5, dapat diketahui bahwa semua variabel independen mempunyai nilai VIF lebih kecil daripada 10 dan nilai tolerance lebih besar dari 0,10, sehingga dapat disimpulkan bahwa model bebas dari multikolinearitas. 


\section{Uji Heteroskedastisitas}

Uji heteroskedastisitas bertujuan untuk menguji apakah dalam model regresi terjadi ketidaksamaan variance dari residual satu pengamatan ke pengamatan yang lain. Jika variance dari residual satu dengan pengamatan lain tetap, maka disebut Homoskedastisitas dan jika beda disebut Heteroskedastisitas. Model regresi yang baik adalah yang tidak terjadi Heteroskedastisitas.

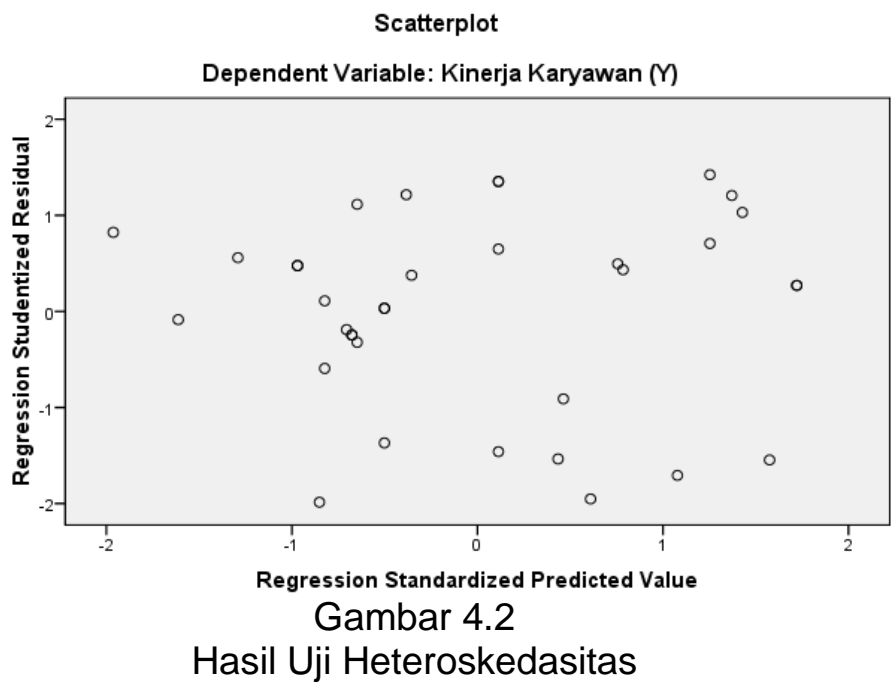

Dapat dilihat dari gambar diatas bahwa titik-titik menyebar diatas dan dibawah angka 0 pada sumbu $Y$ tanpa membentuk pola tertentu, yang artinya dalam penelitian ini tidak terjadi heteroskedasitas pada model regresi atau tidak terjadi ketidaksamaan variance dari residual satu pengamatan kepengaruh lainnya.

\section{Pengujian Hipotesis}

Pengujian hipotesis dilakukan dengan menggunakan model regresi berganda. Model regresi berganda digunakan untuk memecahkan rumusan masalah yang ada, yaitu untuk melihat pengaruh diantara dua variabel atau lebih. Variabel dependen pada penelitian ini adalah Kinerja Karyawan. Variabel independen pada penelitian ini, diantaranya: Disiplin Kerja dan Kepuasan Kerja. Hasil analisis regresi berganda disajikan pada tabel 4.7 berikut.

Tabel 4.7 Rekapitulasi Hasil Analisis Regresi Linear Berganda

\begin{tabular}{|c|c|c|c|c|c|}
\hline \multirow[b]{2}{*}{ Model } & \multicolumn{2}{|c|}{$\begin{array}{l}\text { Unstandardized } \\
\text { Coefficients }\end{array}$} & \multirow{2}{*}{$\begin{array}{c}\text { Standardized } \\
\text { Coefficients }\end{array}$} & \multirow[b]{2}{*}{$T$} & \multirow[b]{2}{*}{ Sig. } \\
\hline & $B$ & Std. Error & & & \\
\hline (Constant) & 7,212 & 3,501 & & 2,060 & 0,048 \\
\hline Disiplin Kerja & 0,604 & 0,239 & 0,468 & 2,528 & 0,017 \\
\hline Kepuasan Kerja & 0,506 & 0,198 & 0,473 & 2,554 & 0,016 \\
\hline
\end{tabular}

a. Dependent Variable: Kinerja Karyawan

Sumber: Data Diolah, 2020

Berdasarkan perhitungan regresi linear berganda pada tabel 4.7, maka didapatkan hasil persamaan regresi sebagai berikut.

$\mathrm{Y}=7,212+0,604 \mathrm{X}_{1}+0,506 \mathrm{X}_{2}+\varepsilon$ 
Konstanta 7,212 menunjukan bahwa apabila variabel Disiplin Kerja dan Kepuasan Kerja bernilai konstan, maka rata-rata nilai variabel Kinerja Karyawan adalah sebesar 7,212. Koefisien regresi Disiplin Kerja sebesar 0,604 berarti bahwa apabila terdapat penambahan Disiplin Kerja sebesar 1 satuan, maka Kinerja Karyawan akan meningkat sebesar 0,604 satuan. Koefisien regresi Kepuasan Kerja sebesar 0,506 berarti bahwa apabila terdapat penambahan Kepuasan Kerja sebesar 1 satuan, maka Kinerja Karyawan akan meningkat sebesar 0,506 satuan.

\section{Pembahasan Hasil Penelitian \\ Pengaruh Disiplin Kerja Dan Kepuasan Kerja Terhadap Kinerja Karyawan}

Hasil penelitian ini menunjukkan bahwa, disiplin kerja dan kepuasan kerja secara bersama-sama berpengaruh positif dan signifikan terhadap kinerja karyawan pada Hotel Banyualit Spa'n Resort. Hal ini mengidentifikasikan bahwa setiap perubahan yang terjadi pada variabel bebas yaitu disiplin kerja dan kepuasan kerja dapat meningkatkan kinerja karyawan. Hal tersebut sejalan dengan penelitian Meiliana et al. (2019) menunjukkan bahwa disiplin kerja dan kepuasan kerja secara simultan (bersama-sama) mempunyai pengaruh signifikan terhadap kinerja karyawan laboratorium. Selain itu, Prasetyo \& Marlina (2019) menunjukkan bahwa disiplin kerja dan kepuasan kerja berpengaruh positif terhadap kinerja karyawan. Hal tersebut menunjukkan bahwa, semakin tinggi tingkat kedisiplinan karyawan dan tingkat kepuasan karyawan maka semakin meningkatnya kinerja karyawan.

\section{Pengaruh Disiplin Kerja Terhadap Kinerja Karyawan}

Hasil penelitian mengenai pengaruh variabel disiplin kerja terhadap kinerja karyawan, diperoleh hasil variabel disiplin kerja secara parsial berpengaruh positif dan signifikan terhadap kinerja karyawan. Hal ini mengientifikasi bahwa variabel disiplin kerja dapat meningkatkan kinerja karywan. Hal tersebut sejalan dengan penelitian Paruru et al. (2016) menunjukkan bahwa disiplin kerja berpengaruh positif dan signifikan terhadap variabel kinerja karyawan. Selain itu, Zahara \& Hidayat (2017) juga mengemukakan bahwa terdapat pengaruh yang signifikan antara disiplin kerja terhadap kinerja karyawan. Hal ini dipertegas oleh Untari (2018) yang menyimpulkan bahwa pengaruh antara disiplin kerja dengan kinerja pegawai sangat erat, jika kedisiplinan seorang karyawan baik, maka akan berakibat kinerjanya semakin baik pula. Berdasarkan hal tersebut, dapat disimpulkan bahwa semakin tinggi tingkat disiplin karyawan maka semkin tinggi tingkat kinerjanya.

\section{Pengaruh Kepuasan Kerja Terhadap Kinerja Karyawan}

Hasil penelitian selanjutnya mengenai variabel kepuasan kerja secara parsial berpengaruh positif dan signifikan terhadap kinerja karyawan Hotel Banyualit Spa'n Resort Lovina. Hal ini mengidentifikasi bahwa variabel kepuasan kerja dapat meningkatkan kinerja karyawan. Hasil penelitian ini sesuai dengan pendapat Susanto (2019) bahwa kepuasan kerja akan membentuk kinerja karyawan dalam bekerja, dengan membentuk budaya kerja yang baik akan memberikan rasa nyaman dalam lingkungan dan memiliki kualitas kehidupan kerja yang baik untuk dapat melaksanakan tugasnya dengan tepat sesuai dengan tujuan yang telah ditetapkan oleh organisasi. Kepuasan kerja karyawan tentu memengaruhi kinerja atau tugas seorang karyawan semakin tinggi kepuasan kerja yang diberikan maka semakin baik pula kinerja seorang karyawan. Hal tersebut sejalan dengan hasil penelitian Manik \& Syafrina (2018) mengatakan bahwa kepuasan kerja berpengaruh signifikan terhadap kinerja.

\section{Implikasi}

Berdasarkan hasil penelitian ini, menunjukkan bahwa disiplin kerja dan kepuasan kerja berpengaruh terhadap kinerja karyawan baik secara simultan maupun secara parsial. Oleh karena itu, dari hasil penelitian ini dapat diimplikasikan sebagai berikut: 
1. Disiplin kerja berpengaruh signifikan terhadap kinerja karyawan. Walaupun sudah berupaya menerapkan aturan-aturan terkait disiplin karyawan, manajemen belum sepenuhnya memberlakukan sanksi atau teguran bagi karyawan yang melakukan pelanggaran. Jika tidak ditangani secara khusus, maka kinerja karyawan pada khususnya dan hotel pada umumnya menjadi rendah. Oleh sebab itu, hotel perlu meningkatkan disiplin karyawan seperti, memberikan sanksi pada karyawan yang masih datang terlambat dan tidak tepat waktu dalam menyelesaikan pekerjaannya. Hotel juga dapat memberikan sosialisasi terlebih dahulu mengenai sanksi yang akan diberlakukan. Ketegasan dalam penerapan aturan dan sanksi perlu dilakukan agar tidak dipandang sebagai sekedar aturan oleh karyawan. Aturan-aturan mengenai sanksi perlu diteruskan ke setiap departemen untuk kemudian diteruskan ke unit-unit dalam departemen tersebut. Demikian pula, hotel melakukan pemantauan secara periodik.

2. Kepuasan kerja berpengaruh signifikan terhadap kinerja karyawan. Hotel Banyualit Spa'n Resort perlu menerapkan program khusus untuk meningkatkan kepuasan karyawan dan memperlakukan karyawan sebagai pelanggan internal. Program yang utama adalah survey kepuasan karyawan secara berkala. Melalui program ini, manajemen hotel dapat mengetahui sejauh mana karyawan puas bekerja di hotel. Manajemen hotel juga dapat menggali komentar-komentar karyawan melalui survey tersebut. Hasil analisis survey tersebut dapat dijadikan dasar dalam menentukan kebijakan hotel terkait kepuasan karyawan. Selanjutnya, program yang dapat diberlakukan adalah memberi penghargaan baik berupa sertifikat maupun bonus pada karyawan yang memiliki kinerja baik. Demikian pula, manajemen hotel perlu mengawasi kinerja karyawan dan menaikan jabatan saat karyawan memperoleh prestasi. Hal tersebut akan menumbuhkan semangat karyawan dalam bekerja secara maksimal. Kepuasan karyawan dapat juga menjadi alasan bagi karyawan untuk berhenti bekerja. Hal ini akan berdampak buruk jika turn over karyawan tinggi dan jika karyawan yang berkualitas berhenti.

\section{SIMPULAN DAN SARAN \\ Simpulan}

Berdasarkan hasil pengujian statistic dan hipotesis serta pembahasan yang telah dilakukan dapat ditarik simpulan sebagai berikut:

1. Disiplin kerja dan kepuasan kerja secara bersama-sama berpengaruh secara signifikan terhadap kinerja karyawan di Hotel banyualit Spa'n Resort.

2. Disiplin kerja secara parsial berpengaruh secara signifikan terhadap kinerja karyawan di Hotel Banyualit Spa'n Resort

3. Kepuasan kerja secara parsial berpengaruh secara signifikan terhadap kinerja karyawan di Hotel Banyualit Spa'n Resort.

\section{Saran}

Berdasarkan hasil simpulan yang telah dipaparkan diatas, maka dapat diajukan saran sebagai berikut.

1. Bagi pihak Hotel Banyualit Spa'n Resort Lovina untuk dapat lebih meningkatkan kualitas kinerja pada karyawan. Terutama dapat meningkatkan kedisiplinan setiap karyawan serta memerhatikan kepuasan kerja bagi karyawan agar dapat memenuhi hasil kinerja yang maksimal.

2. Bagi peneliti selanjutnya yang tertarik untuk mengkaji aspek serupa yaitu disiplin kerja, kepuasan kerja dan kinerja karyawan dapat menguji hubungan ketiga variabel tersebut pada konteks yang berbeda. Selain itu, peneliti selanjutnya menambahkan faktor-faktor lain yang dapat memengaruhi peningkatan kinerja karyawan. 


\section{DAFTAR RUJUKAN}

Almigo, N. (2004). Hubungan Antara Kepuasan Kerja Dengan Produktivitas Kerja Karyawan (The Relation Between Job Satisfaction and Employees Work Productivyty). Jurnal PSYCHE, 1(December).

Arda, M. (2017). Pengaruh Kepuasan Kerja Dan Disiplin Kerja Terhadap Kinerja Karyawan Pada Bank Rakyat Indonesia Cabang Putri Hijau Medan. Jurnal IImiah Manajemen \& Bisnis, 18(1), 45-60.

Asmawiyah. (2018). Pengaruh Motivasi Dan Kedisiplinan Terhadap Kinerja Karyawan Pada Restoran A \& W Mall Trans Studio Makassar. Jurnal IImiah Pena, 1(1).

Bangun, W. (2012). Manajemen Sumber Daya Manusia. Erlangga.

Damayanti, I. (2018). Pengaruh penempatan karyawan kerja dan pengembangan karir terhadap kinerja karyawan pada PT. Citra Van Titipan Kilat (TIKI) di Samarinda. Jurnal IImu Manajemen Mulawarman, 3.

Ernawati, R. (2016). Pengaruh Disiplin Kerja Terhadap Kinerja Karyawan Di Sman 113 Jakarta Timur. J $D P, 9(2), 81-92$.

Fitrianto, I. (2016). Pengaruh Motivasi, Disiplin, Dan Kepuasan Kerja, Terhadap Kinerja Karyawan Pt. Bumi Rama Nusantara. Jurnal Mirai Management, 1(1).

Giyarto, B. (2018). Pengaruh Kepuasan Kerja Dan Disiplin Kerja Terhadap Kinerja Karyawan. Jurnal Ekobis Dewantara, 9(1).

Handoko. (2001). Manajemen Personalia dan Sumberdaya. BPFE.

Hasibuan, M. (2001). Manajemen Sumber Daya Manusia : pengertian dasar, pengertian, dan Masalah. PT. Toko Gunung Agung.

Manik, S., \& Syafrina, N. (2018). Pengaruh Insentif dan Kepuasan Kerja Terhadap Kinerja Karyawan Pada Hotel Grand Zuri Duri. Jurnal Daya Saing, 4(1).

Meilany, P., \& Ibrahim, M. (2015). Pengaruh Disiplin Kerja Terhadap Kinerja Karyawan (Khusus Bagian Operasional PT. Indah Logistik Cargo Cabang Pekanbaru. Jom FISIP, 2(2).

Meiliana, M., Lianty, L., Gunawan, S., Rostina, C. F., \& Nazmi, H. (2019). Pengaruh Disiplin Kerja Dan Kepuasan Kerja Terhadap Kinerja Karyawan Pada Pt. Asia Raya Foundry. Wahana Inovasi, 8(1). https://jurnal.uisu.ac.id/index.php/wahana/article/view/1555

Paruru, J. B., Lapian, S. L. H. V. J., \& Tawas, H. N. (2016). Pengaruh Disiplin Kerja Dan Kemampuan Kerja Terhadap Kinerja Karyawan PT. Air Manado. Jurnal EMBA, 5(1), 225233.

Prasetyo, E. T., \& Marlina, P. (2019). Pengaruh Disiplin Kerja dan Kepuasan Kerja Terhadap Kinerja Karyawan. Jurnal Inspirasi Bisnis Dan Manajemen, 3(1). http://jurnal.unswagati.ac.id/index.php/jibm

Rivai, V. (2003). Manajemen Sumber Daya Manusia untuk perusahaan. PT. Raja Grafindo 
Persada.

Sajangbati, I. A. S. (2013). Motivasi, Disiplin, Dan Kepuasan Pengaruhnya Terhadap Kinerja Pegawai PT Pos Indonesia (PERSERO) Cabang Bitung. Jurnal EMBA, 1, 667-678. https://doi.org/https://doi.org/10.35794/emba.v1i4.2750

Subagio, M. (2015). Pengaruh Kecerdasan Emosional, Motivasi Kerja, Dan Sikap Kerja Terhadap Kinerja Karyawan Pada PT Ithaca Resources. Jurnal Manajemen, 19(1), 101120.

Subakti, A. G. (2013). Pengaruh Motivasi, Kepuasan, Dan Sikap Kerja Terhadap Kinerja Karyawan Di Café X Bogor. Binus Business Review, 4(2).

Sudjadi. (2005). Manajemen Organisasi. Penerbit Pustaka Aksara.

Sumbung, I. L. (2016). Pengaruh Motivasi Dan Disiplin Terhadap Kinerja Pegawai Dengan Pemberian Insentif Sebagai Variabel Moderasi (Studi Kasus Di Sekretariat Daerah Kabupaten Jayawijaya). Jurnal Kajian Ekonomi Dan Keuangan Daerah, 2(1).

Susanto, N. (2019). Pengaruh Motivasi Kerja, Kepuasan Kerja, Dan Disiplin Kerja Terhadap Kinerja Karyawan Pada Divisi Penjualan Pt Rembaka. AGORA, 7(1).

Sutrisno, E. (2013). Manajemen Sumber Daya Manusia. Kencana Perdana Media Group.

Syafrina, N. (2017). Pengaruh Disiplin Kerja Terhadap Kinerja Karyawan Pada Pt. Suka Fajar Pekanbaru. Eko Dan Bisnis (Riau Economics and Business Reviewe), 8(4).

Untari, D. (2018). Pengaruh Displin Kerja Terhadap Kinerja Pegawai Pada Pt. Kie Indonesia. Cano Ekonomos., 7(1).

Winardi, J. (2004). Manajemen Perilaku Organisasi. Prenada Media.

Windari, A., Wilujeng, S., \& Suryaningtyas, D. (2014). Pengaruh Kepuasan Kerja Dan Disiplin Kerja Terhadap Kinerja Karyawan PT. Pos Indonesia (Persero) Malang. Jurnal Riset Mahasiswa Manajemen, 2(1).

Zahara, R. N., \& Hidayat, H. (2017). Pengaruh Kepuasan dan Disiplin Kerja Terhadap Kinerja Karyawan Bank di Kota Batam. Journal Of Applied Managerial Accounting, 1(2), 150-156. 